\title{
Using ICTs to Enhance Students Motivation in Reading English Literature
}

\section{Yaqot Elbechir}

Department of English, University of Djilali Liabess, Sidi Bel Abbes, Algeria

Email address:

elbechirdalila@gmail.com

\section{To cite this article:}

Yaqot Elbechir. Using ICTs to Enhance Students Motivation in Reading English Literature. Arabic Language, Literature \& Culture. Vol. 3, No. 2, 2018, pp. 16-21. doi: 10.11648/j.allc.20180302.12

Received: August 4, 2018; Accepted: August 19, 2018; Published: September 15, 2018

\begin{abstract}
Teaching English has become more challenging than ever. A storm of change is moving in the pedagogy of English language teaching (E. L. T). The new Information and Communication Technologies (ICTs) have played a great role in promoting ELT. This paper aims to investigate to what extent the use of visual aids, for example (animation videos, pictures, films, audio clips and projectors) can be a motivational tool in enhancing students' interest in reading literary texts in order to improve their motivation and language skills. To achieve the aim of the study, a mixed-method approach consisted of observation and questionnaire was used to collect the required data. Therefore, an experiment was carried out with a sample group of 60 Master 1 students at Chlef university where two groups were taught in different ways. The analysis of the data indicated that majority of students had positive attitudes for the use of visual aids to read literary texts. Also, observation by the researcher showed the use of visual aids during the lecture was effective. The use of the ICT tools enhanced the students' motivation to enjoy the lecture processes better and to achieve the lecture goals higher. The study concludes that the use of visual aids enables the students to engage closely with literary texts. That suggests that literature taught by visual aids helps to enhance students' creative and critical thinking skills. Therefore, this study proclaims that teachers changed their attitudes as well as the students had positive attitudes for the use of visual aids, the lecture processes would be more interesting and creative.
\end{abstract}

Keywords: ELT, Visual Aids, ICTs, Motivation, Literary Texts

\section{Introduction}

Considering the increasing difficulty teachers of literature encounter today, following a decreasing interest in reading books, there is a need to motivate students, which ICT resources can help accomplish. In the Algerian English context, where English is officially stated and taught as a foreign language learning English, leaning literature is not easy. This difficulty arises because learning literature in English as a foreign language class always poses many language and cultural obstacles. Learners find it difficult to comprehend literary texts well. Thus, most teachers should think of the use of ICTs in teaching literature in their EFL classroom in order to better their lectures. The emergence of Information and Communication Technology (ICT) has made it possible for teachers and students to collaborate with each other in diverse ways. [1] Surely, ICTs cannot replace the teacher as such, but the use of ICTs can supplement the traditional mode of teaching English literature. In the present context of technology and information era, traditional mode of teaching seems monotonous and in most of the universities across the country, literature is taught traditionally where the teacher is the only one involved in explaining and talking for one hour or more then leaves the class. The students too get tired of the monotonous every day routine. Students become passive receivers in class while the teacher dominates the whole teaching activities. Many students get used to "listening to" teacher lecture willing to be active thinkers in reading class. However, the situation is extremely different in conversation class. Many students often have no motivation to learn some literary genres such as poetry. Thus, the design of multimedia material and the management of innovation seem to be one of the most helpful teaching methods of literary texts. The main objective of this study is to analyze EFL students' perceptions on the use of visual aids as a motivational tool in cultivating students' interest in reading literary texts used in the English syllabus. The paper intends 
to answer these questions: Does the use of the ICTs in teaching learning English literature enhance students' motivation in reading literary texts? And how can the use of ICT tools enhance students' motivation in reading English literature?

\section{Literature Review}

\subsection{English Literature}

English literature is the most popular courses of study in schools, colleges and universities not only in England but also in the whole world. It is the study of literature written in the English language even if the writer is not from England. Thus, it seems difficult to be learnt easily in an EFL classroom in. [2] According to Povey in [3], in literary text works the vocabulary usage is 'extensive' and 'subtle', and the syntax is 'complex' and ' exact'. English literature covers every major genre and style of writing. There are five genres commonly taught in the classroom: poetry, drama, prose, non-fiction and media. Fiction literary texts that include dramas and poems have some elements as characters, plot, setting, theme, perspective, style, language and structure. Dramas use the elements of novels and short stories. Poems use elements such as structures, rhythm, rhyme, imagery and figurative language.

\subsection{Teaching English Literature with ICT}

A study conducted by Hirvela and Boyle in [4] shows that the main aspects causing particular trouble in literary reading including interpretation of theme, vocabulary, cultural differences, literary style and structure. Consequently, teaching and learning English literature for EFL students seems difficult since the EFL students have lack of language proficiency and inadequate supply of teaching to comprehend better and easily any literary text. [5] According to previous studies, most EFL students have negative attitude towards reading English literary books. Therefore, teaching and learning English literature may need the integration of a new tool that is the integration of ICT. There are numerous benefits in using ICTs in teaching English literature which are of great importance to improve reading interest among students. The use of visual aids in teaching literary texts creates strong engagement between students and the texts. [6] The use of ICTs such as pictures, videos and projectors encourage students to read the literary texts with interest, which make it easier for them to understand the abstract ideas in the text, in [7]. This means while teaching them students supposed to be transformed from the era of writing to the era of images so as to attract learners' attention to read and engage in such genres. ICTs can facilitate teaching literature by doing away boredom and making the student interested in what is being taught. [3] A motivated reader is the one who has fun and excitement about what he is reading, students have to enjoy the book they are supposed to read. The integration of ICTs can motivate and keep the students engaged because ICT tools work at different levels- the students can have an opportunity to see, read, visualize, hear, ponder, discuss, interact and learn. This can be achieved through various means involving ICT. Similarly, in research related to the use of multimedia applications for language teaching and learning literature, it has been stated that the integration of visual aids in teaching creates authentic communication between students and literary texts. [8] In a study conducted by Sivapalan, Wan Fatimah Ahmed and NurKhairunIshak in [9], the importance of audio visual and other visual aids in enhancing students' interest in learning literature was shown in [10]. For instance the use of video and voice clips in teaching poems is vital because' it could help the students emphasis on the significance of different frequencies of sound through which the mind understands poetry naturally, promptly, smoothly, permanently and, thus, more pleasantly'. [11] Moreover, the use of ICTs in teaching literature helps students to comprehend with the literary concepts. Teaching and learning English literature in EFL classroom is challenging. [12] Hence in order to cope with learning challenge, visual aids such as graphics, illustrations, pictures, audio and video can be used as a helpful tool to facilitate students' understanding of the literary concepts occurred in the texts in [12] because of their color, sound and light that attract students' attention and therefore they can understand the texts. Thus, the integration of ICTs is necessary to teach EFL students literary texts.

Most students find that literature is hard to be understood and that it is difficult to be read since learners are not interested in reading literature through books. This generation of learners is called e- learners. They believe in what they see and hear. They are not much interested in what is written. Thus learning literature requires to be integrated with the use of ICT tools to make what is written be seen and heard and therefore it may be attractive and motivating

\section{Methodology}

This study applies method approach, whereby quantitative and qualitative methodology was utilized. The data collection was based on observation. Observation is regarded as a qualitative approach since it is a tool to collect primary data about the interaction in a group or behavior. It is also considered as a purposeful, systematic and selective way of watching and listening to an interaction as it takes place. Observations are used to focus on human meanings, interpretations and interactions that are valuable. [13] Observation is the best method or approach to collect data about the interaction, the behavior or the personality characteristics of an individual. Useful observations in this case study were made when the researcher attended the literature components. The researcher stayed at the back of the classroom throughout the lesson and took notes to describe the settings and the transactions that took place as well as making comments on any remarks made. The A questionnaire is another research tool used as a quantitative approach to collect data. It was prepared and distributed for the purpose of securing 
responses and information about certain conditions or practices, of which recipient is presumed to have knowledge. The questionnaire is considered to be the most flexible of tools and possesses a unique advantage over others in collecting information. The questionnaire respondents consisted of 60 Master 1 students at Chlef university, Algeria studying English as a foreign language. The participants were divided into two groups A and B. Each group consists of 30 students. The age range of the students involved in the study was 22-23 years old.

The researcher was granted of permission to attend and observe the processes of the literature lectures by the participants who were taught and a teacher of English literature who agreed to help to implement the researcher's experiment that is to teach a literary text which included a poem programmed by the department of English using visual aids for group A. For the control, group B was taught the same lecture using the traditional mode of teaching literature. The total number of the sessions observed was four with each group. One session for each group per week and each session lasted one hour and half. After the end of the lecture, a questionnaire was designed and served to the participants (of group A and B) to obtain specific information about students' attitudes, what cannot be directly observed, such as feelings, thoughts, intentions, or beliefs. The methodology of this current study does not include group $\mathrm{C}$ for placebo effect, but it can be designed for further research.

\section{Findings and Discussions}

\subsection{Findings}

\subsubsection{The Use of Visual Aids in Teaching Literary Texts}

An experiment was formulated to collect data. The data collection instrument was observing two literature lectures by the researcher. Firstly the participants in group A were taught a literary text with the use of ICTs while group B were taught the same literary text without the use of ICT tools in order to answer the research questions. The teacher with group A taught the students the romantic poem adopting different types of ICT tools. The teacher put up on screen the poem through slide shows accompanied by its corresponding painting. This widely simplified the poem for the learners who seemed more interested in learning such literary text. Another ICT tool used by the teacher was an audio version which was played where the poem was recited by the native speaker. This listening to the poem's recitation would help making an impact on the minds of the students and would enjoy responding to it. $\mathrm{T}$ he picture of the poet was also shown and other different pictures in varied settings which were related to the poet's biography, and while the pictures were played, the biographical details were discussed by the teacher similarly in order to give a feeling of the romantic age. The combination effect of the visual and hearing aids would make students experienced what is being taught. In the second and third sessions, the themes images and movement of the poem were discussed through the different slides which were innovative and effective. In the final session, as it was observed, the teacher designed an activity to the students. After the time devoted to answer the activities, the majority of the students share their responses interestingly and comprehensively. They were more motivated and seemed more interested in learning this literary text. Whereas, the participants of group B were taught the same poem with the same teacher, but in a fairly traditional manner. As it was observed, the teacher started the lecture by reading the poem. The students seemed not interested in hearing what the teacher was saying. The teacher found himself obliged to translate many of vocabularies into French that is considered as L2 for them. This was because the learners could no longer response to the poem. Then, he was trying to explore the main ideas. The teacher directly started to explore some of the key themes and discussing them alone all the session. He also dictated the poet's biography to the students and asked them to write down on their note books. They obviously seemed bored and the poem too seemed boring and not interesting compared with teaching it with group A. In the second and the third sessions, the teacher looked at the poem's structural and stylistic traits. He tended to explain them alone also all the time sessions. In the final session, the same designed activities given to group A were given to group B. The students were required to give their answer after a period of time, as it was observed, the teacher asked the class to call out their answers, the majority of the learners failed to answer. This was due to the misunderstanding of the poem, this was due to the traditional recitation of the poem because the real beauty and meaning of poetry lies in its recitation. The best answers were confined only to very few students.

The observation results revealed that the method used in teaching the poem with group A, that is the integration of ICT tool, effectively motivated the students. As it was observed that the visual aids of the voice clips used to recite the poem presentation of the poem including the corresponding pictures and painting, boosted and motivated the students to response to the poem successfully and in a short time after the start of the lecture. The students seemed interested in reading the text. This was illustrated by the students responses to the poem when the majority of them shared their answers of the designed activities given by the teacher at the end of the lecture and they created communicative conversation. This is because the use of the audio version in reciting the poem was effective. All this demonstrates that the visual and audio aids provided really enhanced the students' motivation to learn English literature since they contributed to make the students interested in reading the poem and understand the abstract ideas in the poem because these tools simplified and facilitated the most difficult genre in literature that is poetry.

On the other hand, the observation results gathered during teaching the same lecture by the same teacher with group B revealed that the absence of the ICT tools in teaching the poem made the students felt bored. The students seemed not interested in learning the literary text that itself seemed 
boring. As it was observed there was no motivation among the students to response to the poem. Indeed most of the students didn't share any answers. This demonstrates that the absence of ICT tools in teaching English literary texts cause lack of motivation among students.

\subsubsection{Students' Attitudes for the Use of Visual Aids in Literature Components}

This section presents the students' attitudes for the use of ICT tools in learning literature components of group A. The distribution of frequency in each item is shown in table 1

Table 1. Students' attitudes for the use of ICT tools in learning literature components agree.

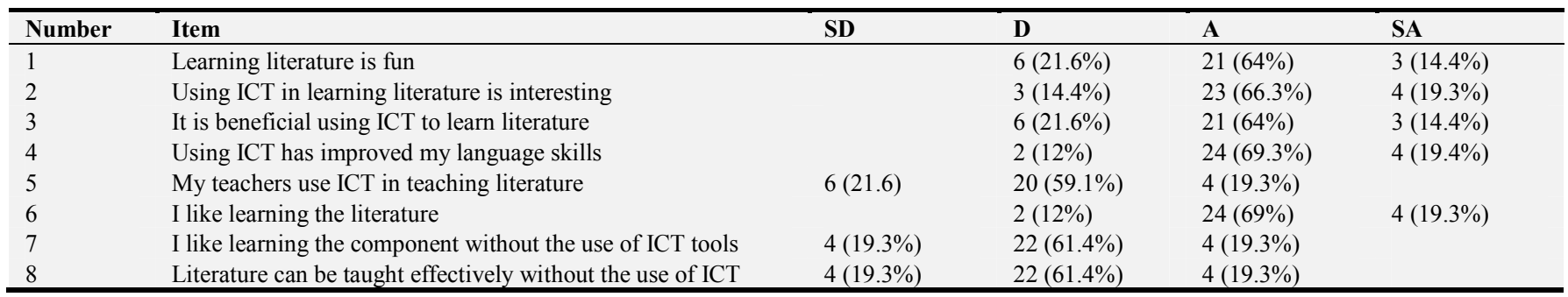

SD: strongly disagree, D: disagree, A: agree, SD: strongly

The first questionnaire results analysis showed that the majority of students have high positive attitude towards the use of ICT tools in learning literature. The results demonstrated that $(60 \%)$ to $(70 \%)$ of the students in group A agreed on the use of ICT tools. From this, it could be interpreted that the students felt positive towards the use of the visual aids during the lecture. A high percentage of students agreed (69\%) and strongly agreed $(19.3 \%)$ on the item "I like learning the literature component with the use of ICT" and (69\%) of the students agreed and (19.3\%) strongly agreed on the item "Using ICTs has improved my language skills". And (66.3\%) of the students agreed and (30.7\%) strongly agreed on the item" Using ICTs in learning literature is interesting" and (64\%) agreed and (14.4\%) strongly agreed on the item "It is beneficial to use ICTs to learn literature". This demonstrates that students like learning literature with the integration of ICTs and that they are aware of its importance in facilitating literature. This was probably because students realized that learning literature visually helped them in their personal growth, cultural enrichment and most importantly language development. This is supported by the following items that showed a majority of the students above (80\%) disagreed on "I like learning literature component without the use of ICTs ", " Literature can be taught effectively without the use of ICTs ". This means that students are of great need to the use of ICTs in teaching literature.

\subsubsection{Students' Attitudes for Learning Literature Components Without ICT Tools}

This section provides an insight on students' attitudes in learning literature components without the use of the ICT tools. Group B, as illustrated in table 2

Table 2. Students' attitudes for learning literature components without ICTs.

\begin{tabular}{|c|c|c|c|c|c|}
\hline Number & Item & SD & D & $\mathbf{A}$ & SA \\
\hline 1 & Learning literature is fun & & $6(21.6 \%)$ & $21(64 \%)$ & $3(14.4 \%)$ \\
\hline 2 & English literature is important & & $2(12 \%)$ & $24(69.3 \%)$ & $4(19.3 \%)$ \\
\hline 3 & English literature is boring and not interesting & & $2(12 \%)$ & $23(66.3 \%)$ & $4(19.3 \%)$ \\
\hline 4 & Learning English literature is difficult & & $6(21.6 \%)$ & $20(59.1 \%)$ & $4(19.3 \%)$ \\
\hline 5 & English literature is hard to understand & & $6(21.6 \%)$ & $21(64 \%)$ & $3(14.4 \%)$ \\
\hline 6 & My teachers use ICT in teaching literature & $3(14.4 \%)$ & $24(69.3 \%)$ & $3(14.4 \%)$ & \\
\hline 7 & I like learning literature & & $4(19.3 \%)$ & $24(69.3 \%)$ & $2(12 \%)$ \\
\hline
\end{tabular}

SD: strongly disagree, D: disagree, A: agree, SD: strongly agree

The second questionnaire results revealed that students were in negative attitudes for learning English literature without the use of ICTs. Despite the fact that they believed "Literature is important" (69.3\%) agreed and (19.3\%) strongly agreed as well as "I like learning the literature component "students found "English literature is difficult" (59.1\%) agreed and "English literature is hard to understand" $(64 \%)$. This might imply that students need a suitable tool to be interested in reading literary text to better their understanding. This is illustrated by the item "I like learning the literature component with ICTs "whereby (66.3\%) agreed and $(21.6 \%)$ strongly agreed. This demonstrates that absence of ICT tools in learning English literature leads to the absence of motivation. (69.3\%) of students disagreed on "My teacher use ICTs in teaching literary texts". Perhaps the students knew that learning English literature effectively needs the use of visual and audio version to be easily understood. Consequently, motivation among students could be enhanced in reading literary texts by the use of visual aids. As it was argued by Chacko, learning literature is not easy. Due to that, students should look up for alternatives in order to engage themselves better in the lesson. Muller (2006) claimed that the use of films, for instance, helps the students to visualize clearly the literary theory and cultural aspects 
embedded in the texts in [14]. Moreover, literature deals a lot with abstract ideas and thus it really needs the students to do a lot of critical analysis.

\subsection{Discussion}

The current study investigates using ICTs to enhance students' motivation in reading English literature. The findings of the study can be summarized under three parts which are the literature lessons' observation, students attitudes towards using ICT tools in literature lesson and students' attitudes towards learning literature without using ICT tools

Based on the observation of the literature lesson, the observation results demonstrate that teaching and learning literary texts with group A using the ICT tools was more motivating and interesting than group $\mathrm{B}$. This confirms that ICT tools have much effort to offer in terms of encouraging students to be interested in literature lectures. Melor claimed that the ICT provides a variety of learning opportunities for students to learn language which includes the learning of literature texts. [15] Therefore, ICTs can function in assisting students better understanding of the literature lesson and improve students motivation in learning English literature.

Regarding the students attitude towards using ICT tools in learning literary texts, it was revealed that the students expressed positive attitudes towards the use of ICT tools in learning literature. The findings showed that high percentage of students agreed on "I like learning literature component with the use of ICT" and that "Using ICT improved my language skills". It is important for students to possess positive attitudes for using ICT tools in literature; it is likely to be a personal factor which could influence the person on the use of ICT. [16] The use of ICT tools in teaching and learning literature enables the students to read literary texts interestingly and easily. Thus this will improve the outcome of learning literature.

Concerning the students' attitude towards learning literature without ICT tools, the results revealed that the students possessed negative attitudes towards learning literature without ICT tools. Although the students believed that "English literature is important and fun" and that " they like literature component", the students found the component is seen 'difficult' and ' hard to understand'. This is due to the absence of the visual and audio version in the lesson that could simplify and facilitate the literary text; consequently, motivation among students could be enhanced in learning literature. As argued by Chacko, learning literature in English is not easy. Due to that students should look up for alternatives in order to engage themselves better in the lecture. [2]

As a result, teachers are required to use ICT tools in the teaching of literature component. The findings indicated that high percentage of students claimed that their teachers had a low usage of ICT tools in teaching literature. In fact in teaching literature, ICT tools can be of a great help. Teaching literature is not every teacher's cup of tea. Thus, teachers of literature had better use ICT tools as an educational tool to improve the way the students learn and understand difficult concepts in much more effective ways. Actually, teachers should vary their strategies in teaching literature. Using a variety of teaching strategies is another way to improve students' attitudes. [14] Thus, using ICT tools is necessary in motivating learners and facilitating learning literature.

\section{Conclusion}

The findings of this study are useful not only for the lecturers who teach students of English literature and trainee teachers at the teacher training colleges, universities and other educational institutes, but also to the teacher of English at schools. This study investigates using the visual aids to improve students' motivation in reading English literature. It was found that the teachers' integration of ICTs in teaching English literature lectures had a great impact in motivating students to read literary texts since teacher's implementation of visual aids in teaching helps their students concentrate on the lecture and being aware of the expectations and needs in literature teaching. When the teachers know how to grab students' attention, teachers can provide a friendly and interesting atmosphere for the students to learn. Using ICT tools such as power point slides and audio version was valuable in addressing learners' needs such as language difficulty. Whereas, the traditional lecture method in teaching literature component made students not feel interested in learning it. Furthermore, the integration of ICTs in teaching English literature is less time consuming. As a result, the teachers will have more ample time to create enjoyable classroom activities and conduct an effective teaching learning process.

\section{Implications}

From the findings of this study, both groups were aware that ICT tools facilitate and motivate learning English literature even though it is difficult to learn. Here are some implications in literature:

ICT provides changes in literature teaching methodology from a traditional text- based learning to text plusmultimedia

The use of multimedia creates an opportunity for teachers to recast their own understanding of the role text in the teaching and learning of literature, and, accordingly, their own beliefs about and roles on teaching and learning process

The use of multimedia has enormous potential in the classroom, with a number of advantages for experiencing literary texts:

1. All the language skills (listening, reading, speaking, writing) as well as viewing skills are developed.

2. Literature teaching / learning with multimedia provides an approach that is new and attractive, compared to conventional textbooks in which verbal meaning predominates.

3. It suggests interactive activities and provides opportunities for students to study authors, texts and 
contexts using variety of technological resources.

4. Students apply a wide range of strategies to experience, comprehend, interpret and evaluate texts.

5. Students learn more effectively and more efficiently when teaching methods match their preferred learning styles. They are mostly motivated by a variety of integrated teaching materials, methods and contexts.

6. The integration of ICTs support independent learning through student control of information and events and can thus promote student-centered learning.

\section{References}

[1] M. Marshall. Love and Death in Eden: Teaching English Literature to ESL Students. TESOL Quarterly, 13 (3), 1979: 331-340.

[2] J. Chacko. ESL Learners Perceptions Towards The Learning of Literature in English. Master Thesis Unpublished. University Putra Malaysia. 4739 (2), 2007.

[3] J. Povey. Literature in TESLprograms: The languageand the culture. In H. Allen and R. Campbell (ed.) Teaching English as a second language. New York, McGraw-Hill, 1972.

[4] A. Hirvela and J. Boyle. Literature Courses and Student Attitudes. ELT Journal 42 (3), 1988:179-184.

[5] G. K. Sidhu. Literature in the Language Classroom: Seeing through the Eyes of Learners. In M. E. Vethamani, Teaching of Literature in. ESL/EFL Contexts, 2003: 88-110.

[6] B. M. Bowen. Look Here! Visual Aids in Language Teaching. London: Macmillan Publishers Ltd. 1982.

[7] C. G. Bellver. Literature and Visual Aids: Textual, Contextual, and Intertextual Applications. Hispania, 72 (4), 1989: 10781082 .

[8] Vethamani, M. E. A New Call: Computer Applications for Literature Learning. Internet Journal of e- language Learning and Teaching, 1 (2), 2004: 58-72.

[9] S. Sivapalan, Wan Fatimah Ahmad \&NurKhairunIshak. A Web-Based Multimedia Approach to Literature in Malaysian Secondary Schools: Designs and Learning Preferences. International Journal of Instruction 2061 (2), 2011.

[10] S. Sivapalan. Human identification from video using advanced gait recognition techniques. Queensland University of Technolog. 2014.

[11] R. Vijay Kumar,. Shalini Jayanthi. Use of ICT in English Language Teaching and Learning. Journal of English Language and Literature (JOELL), An International Peer Reviewed Journal. 2 (3) 2016.

[12] Rosli Talif. Teaching Literature in ESL: The Malaysian Context. (1995).

[13] N. K. Denzin, \& Y. S. Lincoln, Strategies of Qualitative Enquiry. Thousands Oaks, CA, London. (2003).

[14] Muller, V. Film as Film: Using Movies to HelpStudents Visualize Literary Theory. The English Journal, 95 (3), 2006: 32-38.

[15] Melor Md Yunus, Maimun Aqsha Lubis \& Chu, P. L. Language Learning via ICT: Uses, Challenges and Issues. WSEAS Transactions on Information Science and Applications 9 (6), 2009: 1453-1467.

[16] Melor Md Yunus \& Ashairi Suliman. Information \& Communication Technology (ICT) Tools in Teaching and Learning Literature Component in Malaysian Secondary Schools. Canadian Center of Science and Education 10 (7), 2014: 136. 